\title{
Life history told by a whale-louse: a possible interaction of a southern right whale Eubalaena australis calf with humpback whales Megaptera novaeangliae
}

\author{
Tammy Iwasa-Arai ${ }^{1,2^{*}}$, Salvatore Siciliano ${ }^{3}$, Cristiana S. Serejo ${ }^{2}$ and Ghennie T. Rodríguez-Rey 4,5
}

\begin{abstract}
Southern right whales (Eubalaena australis) are known to host three species of whale-lice, Cyamus gracilis, Cyamus ovalis and Cyamus erraticus. Such cyamids usually are generalists in toothed whales (Cetacea: Odontoceti) and hostspecific in baleen whales (Cetacea: Mysticeti), and because they have no free-swimming stage, transmission only occurs by contact between whales. One southern right whale stranded at the southeastern coast of Brazil was found parasitized by a different species of cyamid. Over 300 specimens were collected and the only species identified based on morphological and molecular data was Cyamus boopis, a typical ectoparasite of humpback whales (Megaptera novaeangliae). This finding is the first record of C. boopis on the southern right whale. Both E. australis and M. novaeangliae are found in Brazilian waters and the presence of humpback's whale-louse together with the lack of the three specific parasites of right whales suggest an interspecific interaction between these whales based on the parasite's biology.
\end{abstract}

Keywords: Whale-lice, Interspecific interaction, Cyamus, Mysticeti

\section{Background}

Southern right whales Eubalaena australis (Desmoulins, 1822), which are observed in Brazil typically from May to December with peaks during August to October, prefer to use shallow and protected areas of the state of Santa Catarina (southern Brazil) as their wintering ground [1, 2]. Sightings of E. australis in southeastern and northeastern Brazil are reported occasionally [3-6] from early July to late October [3]. Although sightings of E. australis are periodic, strandings in southeastern Brazil are rare: only eight strandings, most of which were calves, were recorded between 1936 and 2001 [3]. Figueiredo et al. [7] reports on the last records of right whales in southeastern Brazil.

\footnotetext{
*Correspondence: araitammy@gmail.com

1 Programa de Pós-Graduação em Zoologia, Museu Nacional/

Universidade Federal do Rio de Janeiro, Rio de Janeiro,

RJ 20940-040, Brazil

Full list of author information is available at the end of the article
}

An unusual stranding of a southern right whale calf is reported here. On January 17th, 2004, a whale calf became stranded at Praia de Itaúna, Saquarema, which is located on the east coast of the state of Rio de Janeiro, Brazil, but it died shortly afterwards. The whale's body was in a carcass state of Geraci 1 (fresh) [8] for about $2 \mathrm{~h}$ and $30 \mathrm{~min}$ prior to the necropsy. The subsequent necropsy of this specimen revealed over 200 specimens of epibionts, including pedunculate barnacles Conchoderma auritum (Linnaeus, 1767) and cyamids.

The cyamids or whale-lice are crustacean parasites, which feed on the skin of cetaceans, that are represented by seven genera and 29 species [9-11]. They are considered generalists in toothed whales and dolphins (Odontoceti) and host specific in baleen whales (Mysticeti) [12, 13], therefore, new records of cyamids from slow moving great whales are unlikely, since most studies on the commercially valuable whales cyamid fauna was driven during the whaling period $[9,10]$. For this reason, current 
works on new species and distributional records of Cyamidae are restricted to odontocetes parasites [10, 14].

Right whales are known to host three species of cyamids: Cyamus ovalis Roussel de Vauzème, 1834, Cyamus erraticus Roussel de Vauzème, 1834, and Cyamus gracilis Roussel de Vauzème, 1834 [15-17]. Each species has a different spatial distribution on the right whale's body $[12,15,18]$.

Young calves of right whales usually present Cyamus erraticus on the head and these lice patches tend to disappear within a few months and migrate to soft skin such as genital and mammary slits in right whale adults, whereas the head patches are substituted by Cyamus ovalis and Cyamus gracilis $[15,17]$. Thus, the calf's first louse infestation occurs by vertical transmission from its mother and subsequent horizontal transfer is expected to occur infrequently, which might reflect patterns of behavioral interactions among whales [17]. According to Page and Charleston [19], horizontal transfer is one of the events that contributes to patterns of association between hosts and parasites.

In this study, we report an atypical whale louse parasitizing a southern right whale stranded on the Southeastern coast of Brazil and we discuss the possible implications of this cyamid host change.

\section{Methods}

Cyamid specimens were collected randomly from the head of the stranded calf, fixed and preserved in ethanol 70\%, and deposited at the Crustacean Collection of the Museu Nacional, Rio de Janeiro (MNRJ). Cyamids were absent in other body parts of the stranded calf. All specimens were observed with Zeiss Discovery V12 AxioCam MRc stereomicroscopes. Juveniles were not identified. One specimen was chosen randomly for scanning electron microscopy (SEM). Specimen preparation for SEM was made following the protocol adapted from Felgenhauer [20], dried at critical point, and sputtercoated with gold. Micrographs were taken with SEM JEOL JSM6390LV at Laboratório Central de Microscopia Eletrônica (LCME/UFSC). Additionally, the cyamids were compared with type series of Cyamus boopis Lütken, 1870, deposited at the Zoologisk Museum, Copenhagen (ZMUC), and comparative material of Cyamus ovalis, Cyamus erraticus and Cyamus gracilis from MNRJ and ZMUC (Table 1).

Five random specimens were subjected to molecular analyses. Total genomic DNA was obtained using a modified CTAB extraction [21]. A fragment of the cytochrome oxidase I gene (COI) was amplified using the Jercy and Patcy primers [17]. Amplification reactions included approximately $30 \mathrm{ng}$ of genomic DNA, $1 \mathrm{U}$ of GoTaq Flexi DNA polymerase (Promega), $3 \mu \mathrm{L}$ of Green GoTaq Flexi Buffer $(5 \times), 0.2 \mathrm{mM}$ of dNTPs, $2.5 \mathrm{mM}$ of $\mathrm{MgCl} 2,0.3 \mu \mathrm{M}$ of each primer, and $4 \mu \mathrm{g}$ of BSA in a final volume of $15 \mu \mathrm{L}$. PCR conditions were: 1 cycle of 2 min at $95^{\circ} \mathrm{C}$ followed by 35 cycles of $20 \mathrm{~s}$ at $95{ }^{\circ} \mathrm{C}, 30 \mathrm{~s}$ at $50{ }^{\circ} \mathrm{C}$, and $50 \mathrm{~s}$ at $72{ }^{\circ} \mathrm{C}$. All PCR products amplified were purified using the Agencourt AMPure PCR purification kit and sequenced in both directions using ABI 3500 automated DNA sequencers (Applied Biosystems). The sequences obtained were edited using Seqman 7.0 (DNAstar Inc.), aligned by the Clustal W algorithm implemented in Mega 6 [22], and deposited in GenBank (accession numbers KX100157 to KX100161). Previously published sequences for representatives of seven Cyamus species were included in the alignment. To identify each sample to species a Bayesian phylogenetic tree was inferred using MrBayes 3.2.6 $\left(\right.$ MCMC ngen $=10 \times 10^{6}$ generations, nchains $=4$, nruns $=2$, samplefreq $=1000$, burninfrac $=0.25$ ) [23]. In this analysis, an HKY + G + I model was chosen to be the best model as indicated by Bayesian information criterion (BIC) implemented in Mega with Caprela scaura Templeton, 1836 as the outgroup. Additionally, the intraspecific diversities and interspecific divergences were estimated in Mega, using the K2P distance model.

\section{Results \\ Morphology}

All 327 cyamid specimens were morphologically identified as Cyamus boopis Lütken, 1870, typical ectoparasite of humpback whales Megaptera novaeangliae (Borowski, 1781) [16, 24]. Based on the present data, this is a first record of C. boopis parasitizing Eubalaena australis.

Table 1 Comparative material of cyamids from Eubalaena sp

\begin{tabular}{lllll}
\hline Ref. no. & Cyamid & Host & Stranding location & Date \\
\hline MNRJ 67664-67667 & Cyamus erraticus & Eubalaena australis & Florianópolis, Brazil (fishing net) & Ago-14 \\
MNRJ 67668_-67672 & Cyamus ovalis & Eubalaena australis & Florianópolis, Brazil (fishing net) & Ago-14 \\
MNRJ 67673_-67677 & Cyamus gracilis & Eubalaena australis & Florianópolis, Brazil (fishing net) & Ago-14 \\
ZMUC CRU-7570 & Cyamus erraticus & Eubalaena glacialis & British Columbia, Canada & 1951 \\
ZMUC CRU-7679 & Cyamus ovalis & Eubalaena glacialis & Iceland & 1892 \\
\hline
\end{tabular}


Cyamus boopis was recently redescribed based on the type material, which was used for comparison on the present study, as well as compared with over 1000 C.boopis from sixteen humpback whales stranded off the Brazilian coast [25]. The identification of $C$. boopis was based on diagnostic characters as the presence of ventral acute processes on pereonites 5-7 and shape of accessory gills (Fig. 1).

Diagnostic features were compared with Eubalaena's typical whale-lice, and it differs from $C$. ovalis by the shape of accessory gills, which are larger and asymmetrical in the later species. Cyamus boopis also presents a slender body compared to $C$. ovalis, however broader than C. gracilis. Cyamus gracilis lacks acute ventral processes on the pereonites $5-7$, while $C$. boopis shows a $1 / 1 / 1$ pairs of acute ventral processes arrangement on pereonites $5-7$, respectively, and $C$. erraticus presents a $2 / 2 / 1$ arrangement. Due to the cyamid succession in right whales, it was expected that the calf would host blooms of $C$. erraticus on its head, instead, the only species found was C. boopis.

\section{Barcoding}

Our molecular analyses suggest that the five sequenced specimens of the right whale calf belong to the species Cyamus boopis, thereby corroborating the morphological results. In the Bayesian phylogenetic tree, the analysed specimens are not closely related to none of the reported
Eubalaena's specific cyamid species, contrariwise, they formed a monophyletic group well supported with the sequences of Cyamus boopis (Fig. 2). Furthermore, the value of divergence between the analysed specimens and C. boopis was $1.4 \%$, value that is within the rank of intraspecific distances (0.9-9.0\%) and far below of the rank of interspecific distance between species of Cyamus (14.2-21.0\%, Table 2).

\section{Discussion}

Based on morphological and molecular data, the only species that was found in the right whale calf was Cyamus boopis, a typical ectoparasite of humpback whales (Megaptera novaeangliae). The fact that we only found Cyamus boopis suggests that the calf might have interacted likely by chance with a humpback whale. Thus, the high concentration of gravid females of C. boopis $(\mathrm{n}=73)$ found on the right whale calf agrees with Rowntree [15] assumption that 'gravid females may move to areas where there is less competition for their younger to "launching" sites where there is more contact between whales and the cyamids have a greater chance of moving to a new host'.

Cyamus boopis is the only cyamid that parasitizes humpback whales, and it colonizes areas with reduced water flow, such as the blowhole, wounds, around barnacles and in the ventral grooves [15]. Also, C.boopis is only found in humpback whales. Unlike the right whales lice, there is no succession of cyamid species in humpbacks,

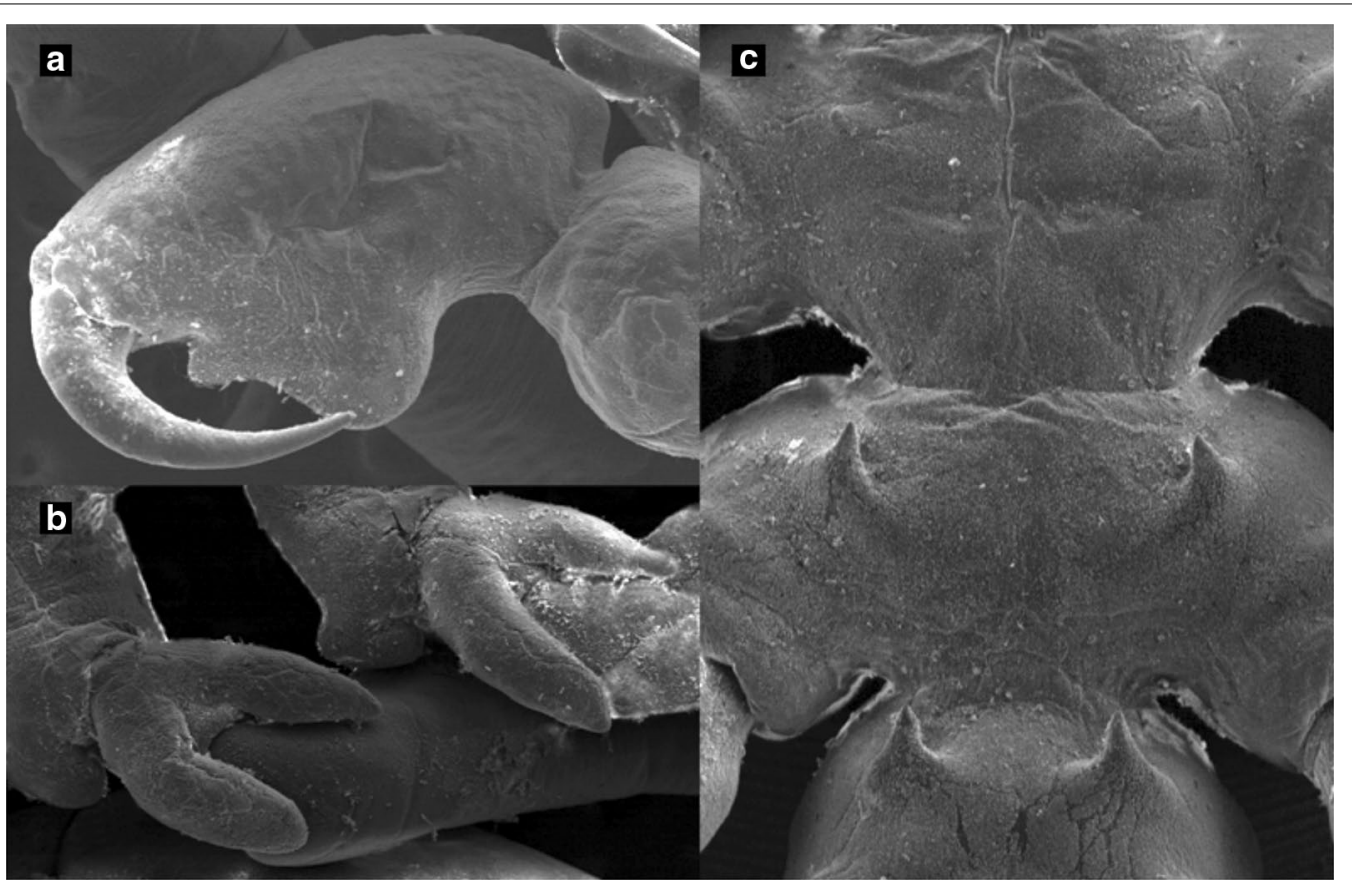

Fig. 1 Morphological diagnostic features of Cyamus boopis found in the southern right whale GEMM-Lagos -0051. a Shape of gnatopod 2; b shape of accessory gills; c number of ventral acute processes on pereonites 5, 6 and 7 


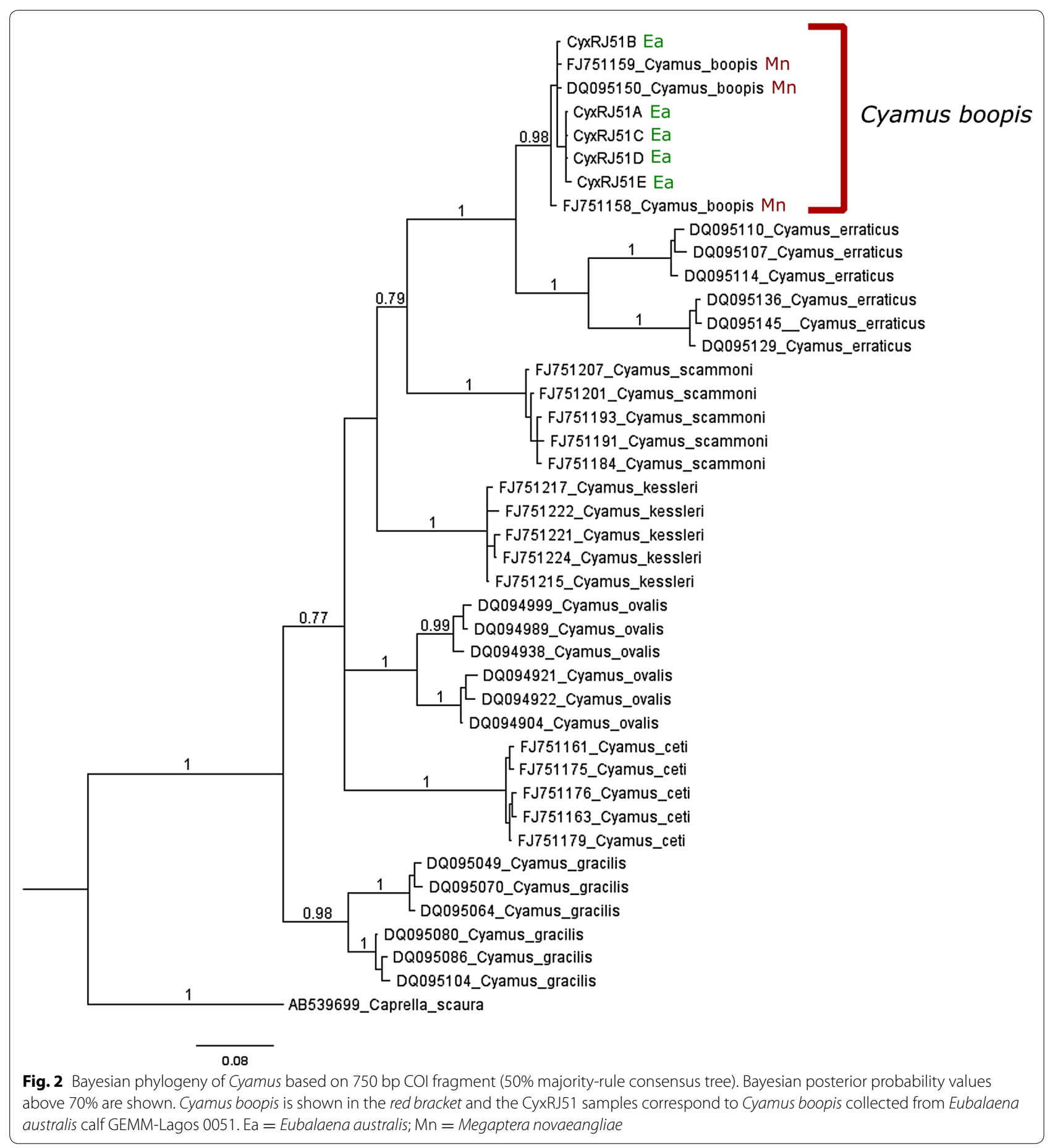

and the only movement of $C$. boopis observed by Rowntree [15] is between small patches of white and black skin within a humpback, which might be driven by the male competition for mates.

Humpbacks are commonly sighted off the east coast of Rio de Janeiro during winter and spring (July-October), though mother and calves of humpback whales as well as yearlings have also been observed along the same coast during austral summer months (December-March) (Salvatore Siciliano, pers. observ.). Reports about interactions between two mysticetes species are less common than interactions between mysticetes and odontocetes [26, 27].

Since cyamids do not have a swimming larval stage and the transmission only occurs by contact between whales 
Table 2 Summary of average Kimura two-parameter distances for Cyamus species

\begin{tabular}{|c|c|c|c|c|c|c|c|c|}
\hline & CyxRJ51 & C. boopis & C. ceti & C. scammoni & C. kessleri & C. ovalis & C. gracilis & C. erraticus \\
\hline C. boopis (CyxRJ51) & 0.006 & & & & & & & \\
\hline C.boopis & 0.014 & 0.009 & & & & & & \\
\hline C.ceti & 0.197 & 0.203 & 0.009 & & & & & \\
\hline C.scammoni & 0.169 & 0.165 & 0.171 & 0.010 & & & & \\
\hline C. kessleri & 0.171 & 0.168 & 0.188 & 0.152 & 0.013 & & & \\
\hline C. ovalis & 0.173 & 0.172 & 0.175 & 0.161 & 0.158 & 0.057 & & \\
\hline C. gracilis & 0.186 & 0.181 & 0.182 & 0.162 & 0.175 & 0.162 & 0.055 & \\
\hline C. erraticus & 0.142 & 0.142 & 0.210 & 0.200 & 0.197 & 0.195 & 0.207 & 0.090 \\
\hline
\end{tabular}

Intraspecific diversities (on the diagonal) and interspecific divergences (below the diagonal)

$[15,28]$, the presence of over 300 Cyamus boopis suggest that the right whale calf unexpected contacted with a humpback whale for a considerable period of time, and the absence of three typical right whale cyamids species raises an inquiry about the nature of the interaction between this right whale calf and a humpback whale and whether it is possible for different baleen whale species to nurse each other. Thus, the transmission of cyamids from Eubalaena to Megaptera whales just recently could be related to the population expansion of humpback whales in the Southwestern Atlantic Ocean [29] and of southern right whales recovering from exploitation [30], which increases the chance of a causal encounter between these two baleen species. While the origin of the cyamid movement onto the right whale calf cannot be known, it is indicative of the first movement of $C$. boopis to a new baleen whale host species.

Our findings show that even though the mysticetes' fauna of cyamids might be well described [31], new occurrences are possible. More information about the cyamid hosts' ecology may yet be revealed by documentation of these ectoparasites. Nonetheless, more effort should be given to collection and sampling of ectoparasites in any dead whale carcass. Collections should be made from fresh carcasses, sampling all the specimens as possible in different areas of the host, and placed into preserved ethanol P.A. for further morphological and molecular studies. This may reveal other new cyamid occurrence and transfers.

\footnotetext{
Abbreviations

GEMM: Grupo de Estudos de Mamíferos Marinhos; MNRJ: Museu Nacional, Rio de Janeiro; SEM: scanning electron microscopy; LCME/UFSC: Laboratório Central de Microscopia Eletrônica/Universidade Federal de Santa Catarina; ZMUC: Zoological Museum of the University of Copenhagen; COl: cytochrome oxidase I; PCR: polymerase chain reaction.
}

\section{Authors' contributions}

TIA conceived the project and perfomed the taxonomic identifications and molecular experiments. GTRR designed and performed the molecular experiments, and interpreted the data. SS collected the material and field data and was a major contributor in writing the manuscript. CSS performed the taxonomic identifications. All authors read and approved the final manuscript.

\begin{abstract}
Author details
${ }^{1}$ Programa de Pós-Graduação em Zoologia, Museu Nacional/Universidade Federal do Rio de Janeiro, Rio de Janeiro, RJ 20940-040, Brazil. ${ }^{2}$ Laboratório de Carcinologia, Departamento de Invertebrados, Museu Nacional/UFRJ, Rio de Janeiro, RJ 20940-040, Brazil. Instituto Oswaldo Cruz/Fiocruz and Grupo de Estudos de Mamíferos Marinhos da Região dos Lagos, Pavilhão Mourisco - sala 122, Av. Brasil, 4365, Manguinhos, Rio de Janeiro, RJ 21040-900, Brazil. ${ }^{4}$ Laboratório de Biodiversidade Molecular, Departamento de Genética, Instituto de Biologia, Universidade Federal do Rio de Janeiro, Rio de Janeiro, RJ 21941-590, Brazil. ${ }^{5}$ Present Address: Departamento de Ciencias Biológicas, Universidad de Caldas, Cl. 65 \#26-10, Manizales, Colombia.
\end{abstract}

\section{Acknowledgements}

The authors are grateful to Eliana de Medeiros (LCME/UFSC) for SEM photos, Dr. Antonio Solé-Cava (IB/UFRJ) for Lab logistical support, Dr. Andrea Freire and Barbara Menezes (UFSC) for C. gracilis, C. erraticus and C. ovalis collection, Dr. Jørgen Olesen and Danny Eibye-Jacobsen (ZMUC) for loan of C. boopis type material. We are particularly thankful to Dr. William Bryan Jennings (Museu Nacional/UFRJ) for the English revision.

\section{Competing interests}

The authors declare that they have no competing interests.

\section{Availability of data and materials}

All data generated or analysed during this study are included in this published article. DNA and RNA sequences are deposited at GenBank mentioned by the accession numbers in the main text.

\section{Consent for publication}

Dr. Salvatore Siciliano, co-author of this manuscript, consent the publication of personal observation and Fig. 1 source. Contact of the author for consent form: gemmlagos@gmail.com

\section{Funding}

This work was supported by the Conselho Nacional de Desenvolvimento Científico e Tecnológico (CNPq) under MSc Scholarship and Grant No. 312343/2015-9.

\section{Publisher's Note}

Springer Nature remains neutral with regard to jurisdictional claims in published maps and institutional affiliations.

Received: 2 November 2016 Accepted: 31 March 2017

Published online: 08 April 2017

\section{References}

1. Groch KR, Palazzo JT Jr, Flores PAC, Adler FR, Fabian ME. Recent rapid increases in the right whale (Eubalaena australis) population off southern Brazil. Lat Am J Aquat Mamm. 2005;4:41-7. 
2. Danilewicz D, Moreno IB, Tavares M, Sucunza F. Southern right whales (Eubalaena australis) off Torres, Brazil: group characteristics, movements, and insights into the role of the Brazilian-Uruguayan wintering ground. Mammalia. 2016. doi:10.1515/mammalia-2015-0096.

3. Santos MCO, Siciliano S, De Souza SP, Pizzorno JLA. Occurrence of southern right whales (Eubalaena australis) along southeastern Brazil. J Cetacean Res Manag. 2001;2:153-6.

4. Wedekin LL, Freitas A, Engel MH, Sazima I. Rough-toothed dolphins (Steno bredanensis) catch diskfishes while interacting with humpback whales (Megaptera novaeangliae) off Abrolhos Bank breeding ground, Southwest Atlantic. Aquat Mamm. 2004;30(2):327-9.

5. Andriolo A, Martins CCA, Engel MH, Pizzorno JL, Más-Rosa S, Freitas AC, Morete ME, Kinas PG. The first aerial survey to estimate abundance of humpback whales (Megaptera novaeangliae) in the breeding ground off Brazil (breeding stock A). J Cetacean Res Manag. 2006;8:307-11.

6. Santos MCO, Siciliano S, Vicente AFC, Alvarenga FS, Zampirolli E, De Souza SP, Maranho A. Cetacean records along São Paulo state coast, southeastern Brazil. Braz J Oceanogr. 2010;58:123-42.

7. Figueiredo GC, Santos MCdeO, Siciliano S, Moura JF. Right Whales (Eubalaena australis) in an urbanized area off the Southwestern Atlantic Ocean: updated records and conservation issues. Aquat Mamm. 43:52-62. doi: 10.1578/AM.43.1.2017.52. (in press).

8. Geraci JR, Lounsbury VJ. Marine mammals ashore: A field guide for strandings. Galveston: Texas A\&M University Sea Grant College Program; 1993. p. 382.

9. Margolis L, McDonald TE, Bousfield EL. The whale-lice (Amphipoda: Cyamidae) of the northeastern Pacific region. Amphipacifica II. 2000:4:63-117.

10. Haney TA, De Almeida AO, Reis MSS. A new species of cyamid (Crustacea: Amphipoda) from a stranded cetacean in Southern Bahia, Brazil. Bull Mar Sci. 2004;75:409-21.

11. De Broyer C. Cyamidae Rafinesque, 1815. In: Horton T, Lowry J, De Broyer C, Bellan-Santini D, Coleman CO, Daneliya M, Dauvin J-C, et al. 2016. World Amphipoda Database. Accessed through: World Register of Marine Species. 2007. http://www.marinespecies.org/aphia. php? $\mathrm{p}=$ taxdetails\&id=158318 Accessed 10 October 2016 .

12. Leung YM. An illustrated key to the species of whale-lice (Amphipoda: Cyamidae), ectoparasites of Cetacea, with a guide to the literature. Crustaceana. 1967;12:279-91.

13. Berzin AA, Vlasova LP. Fauna of the Cetacea Cyamidae (Amphipoda) of the world ocean. Investig Cetacea. 1982;13:149-64.

14. Sedlak-Weinstein $E$. Three new records of cyamids (Amphipoda) from Australian cetaceans. Crustaceana. 1991;60:90-104.

15. Rowntree VJ. Feeding, distribution, and reproductive behavior of cyamids (Crustacea: Amphipoda) living on humpback and right whales. Can J Zool. 1996;74:103-9.

16. De Pina GMA, Giuffra R. Taxonomía, distribuición y notas sobre cuatro espécies de ectoparasitos de Cetacea (Crustacea: Amphipoda: Cyamidae). Rev Mus Argent Cienc Nat. 2003;5:39-62.
17. Kaliszewska ZA, Seger J, Rowntree V, Barco SG, Benegas R, Best PB, Brown MW, Brownell RL Jr, Carribero A, Harcourt R, Knowton AR, Marshall-Tilas K, Patenaude NJ, Rivarola M, Schaeff CM, Sironi M, Smith WA, Yamada TK Population histories of right whales (Cetacea: Eubalaena) inferred from mitochondrial sequence diversities and divergences of their whale lice (Amphipoda: Cyamus). Mol Ecol. 2005;14:3439-56.

18. Callahan CM. Molecular systematics and population genetics of whale lice (Amphipoda: Cyamidae) living on gray whale islands. Dissertation, Humboldt State University. 2008. p 54.

19. Page RDM, Charleston MA. Trees within trees: phylogeny and historical associations. Trends Ecol Evol. 1998;13:356-9.

20. Felgenhauer BE. Techniques for preparing crustaceans for scanning electron microscopy. J Crustacean Biol. 1987;7(1):71-6.

21. Gusmão J, Solé-Cava AM. Um sistema de diagnóstico molecular para a identificação de espécies comerciais de camarões marinhos brasileiros. CIVA. 2002;1:754-64.

22. Tamura K, Stecher G, Peterson D, Filipski A, Kumar S. MEGA6: molecular evolutionary genetics analysis version 6.0. Mol Biol Evol. 2013;30:2725-9.

23. Ronquist F, Huelsenbeck J. MRBAYES 3: Bayesian phylogenetic inference under miced models. Bioinformatics. 2003;19:1572-4.

24. Margolis L. Notes on the morphology, taxonomy and synonymy of several species of whale lice (Cyamidae: Amphipoda). J Fish Res Board Can. 1955; 12:121-33.

25. Iwasa-Arai T, Freire AS, Colosio AC, Serejo CS. Ontogenetic development and redescription of the whale louse Cyamus boopis. Mar Biodivers. 2016. doi:10.1007/s12526-016-0532-z

26. Árnason U, Spilliaert R, Pálsdottir A, Arnason A. Molecular identification of hybrids between the two largest whale species, the blue whale (Balaenoptera musculus) and the fin whale (B. physalus). Hereditas. 1991;115:183-9.

27. Rossi-Santos M, Santos-Neto RE, Baracho CG. Interspecific cetacean interactions during the breeding season of humpback whale (Megaptera novaeangliae) on the north coast of Bahia State, Brazil. J Mar Biol Assoc UK. 2009:89:961-6.

28. Pfeiffer CJ. Whale lice. In: Perrin WF, Würsig P, Thewissen JGM, editors. Encyclopedia of marine mammals. San Diego: Academic Press; 2002. p. 1302-5.

29. Bortolotto GA, Danilewicz D, Andriolo A, Secchi ER, Zerbini AN. Whale, whale, everywhere: Increasing abundance of western south Atlantic humpback whales (Megaptera novaeangliae) in their wintering grounds. PLoS ONE. 2016:11(10):e0164596.

30. International Whaling Commission. Report of the workshop on the comprehensive assessment of right whales: a worldwide comparison, Cape Town, 19-25 March 1998. J Cetacean Res Manag (Special Issue). 2001;2:1-60.

31. Haney TA. A phylogenetic analysis of the whale-lice (Amphipoda: Cyamidae). Dissertation, University of Charleston. 1999. p 232.

\section{Submit your next manuscript to BioMed Central and we will help you at every step:}

- We accept pre-submission inquiries

- Our selector tool helps you to find the most relevant journal

- We provide round the clock customer support

- Convenient online submission

- Thorough peer review

- Inclusion in PubMed and all major indexing services

- Maximum visibility for your research

Submit your manuscript at www.biomedcentral.com/submit 